\title{
Green fluorescent protein purification through Immobilized Metal Affinity \\ Chromatografy (IMAC) and its relevance for Biomedical Science students during Biochemistry practical classes at La Trobe University - Australia
}

\author{
Purificação de Proteína verde fluorescente por meio de Cromatografia de Afinidade com Íon Metal \\ Imobilizado (IMAC) e sua relevância para estudantes de Ciências Biomédicas durante aulas de Bioquímica \\ na Universidade La Trobe - Austrália
}

Alex José de Melo Silva ${ }^{13^{*}}$; Lumar Lucena Alves ${ }^{23}$; Julian Pakay ${ }^{4}$

${ }^{1}$ Biomedical undergraduate student, Federal University of Pernanbuco (UFPE), Recife-PE, Brazil.

${ }^{2}$ Biomedical undergraduate student, Tiradentes University (UNIT), Aracaju-SE, Brazil.

${ }^{3}$ Student of the program Science without frontiers at La Trobe University

${ }^{4}$ Department of Biochemistry and Genetics, La Trobe Institute for Molecular Science, La Trobe University, Melbourne/Australia

*e-mail: ajmsufpe@hotmail.com

\begin{abstract}
This work was performed as an integrated practical of a Biomedical Science undergraduate course of Biochemistry subject, in order to demonstrate used techniques to purify of Green Fluorescent Protein (GFP). To perform the experiments the main methodology applied was the by immobilized metal affinity chromatography (IMAC). The open reading frame for enhanced GFP was sub-cloned into the $P Q E 30$ expression vector. The subsequent production of protein tagged N-terminally with hexahistidine, facilitated its purification by IMAC. An approximate 3fold purification of GFP was achieved. Thus, the students who completed the course gained significant experience related to fundamental techniques in molecular cloning and a sound basis in the principles of recombinant protein expression and purification.
\end{abstract}

Keywords: GFP; Purification; IMAC.

\section{Resumo}

Este trabalho foi realizado como prática integrada da disciplina de Bioquímica no curso de graduação em Ciências Biomédicas, objetivando demonstrar técnicas utilizadas para a purificação da Proteina Fluorescente Verde (GFP). Para realização dos experimentos foi utilizada como metodologia principal a Cromatografia de Afinidade por Metal Imobilizado (IMAC). A região de abertura para alongamento da GFP foi subclonada dentro de um vetor de expressão chamado pQE30. A produção subsequente da proteína marcada com hexahistidina na região $\mathrm{N}$ terminal, facilitou sua purificação pela IMAC. Uma purificação de aproximadamente três vezes mais que a esperada da GFP foi obtida. Dessa forma, os estudantes completaram o curso adquirindo significante experiência em relação às técnicas fundamentais na área molecular relacionadas à clonagem e princípios de expressão e purificação de proteínas recombinantes.

Palavras-chave: GFP; Purificação; IMAC. 
Green fluorescent protein purification through Immobilized Metal Affinity Chromatografy and its relevance for Biomedical Science students during Biochemistry practical classes at La Trobe University- Australia

\section{Record activity performed}

\begin{tabular}{|c|c|}
\hline Title & $\begin{array}{l}\text { Green Fluorescent Protein Purification through Immobilized Metal Affinity } \\
\text { Chromatography (IMAC) and its relevance for Biomedical Science students } \\
\text { during practical classes at La Trobe University-Australia }\end{array}$ \\
\hline $\begin{array}{l}\text { Target } \\
\text { audience }\end{array}$ & $\begin{array}{l}\text { Undergraduate students of the Biochemistry course of La Trobe for Molecular } \\
\text { Sciences, La Trobe University. }\end{array}$ \\
\hline $\begin{array}{l}\text { Related } \\
\text { disciplines }\end{array}$ & Advanced Biochemistry and Medical Biology Laboratory Course \\
\hline $\begin{array}{l}\text { Educational } \\
\text { objectives }\end{array}$ & $\begin{array}{l}\text { Contribute and explain easily concepts in cell and molecular biology using an } \\
\text { appropriate vocabulary; } \\
\text { Apply advanced techniques in molecular biology, protein purification and cell } \\
\text { biology to generate and analyse data and evaluate the experimental protocols } \\
\text { used; } \\
\text { Explain/understand current techniques in Biochemistry and molecular biology; } \\
\text { Collect, analyse and evaluate information from literature to prepare a thorough } \\
\text { scientific report. }\end{array}$ \\
\hline $\begin{array}{l}\text { Justification of } \\
\text { use }\end{array}$ & $\begin{array}{l}\text { Provide experience in current techniques in molecular and medical cellular } \\
\text { biology including functional assays of apoptosis, transfection and fluorescent } \\
\text { microscopy, immunofluorescent microscopy and intergrated practical where } \\
\text { students could clone and express a chimeric protein. }\end{array}$ \\
\hline $\begin{array}{l}\text { Worked } \\
\text { contents }\end{array}$ & $\begin{array}{l}\text { Concepts in cell and molecular biology; } \\
\text { Application of advanced techniques in molecular biology, protein purification and } \\
\text { cellular biology area; } \\
\text { Techniques in Biochemistry and Molecular Biology; } \\
\text { Methodologies to work ethically, cooperatively and safely in a molecular } \\
\text { laboratory; } \\
\text { Application of research methods into molecular biology and understand the } \\
\text { nature of translational research. }\end{array}$ \\
\hline $\begin{array}{l}\text { Estimated } \\
\text { duration }\end{array}$ & From August to November of 2014. \\
\hline Used materials & $\begin{array}{l}\text { Restriction enzymes (BamHI and HindlII), Vector (pQE30), Agarose gel, } \\
\text { thermocycler, E.coli cells, NaCl ( } \mathrm{pH} \mathrm{7.5),} \mathrm{antibiotic} \mathrm{(Ampicillin),} \mathrm{UV} \mathrm{light,} \mathrm{primer} \\
\text { (for PCR technic), phenol/chloroform, ethanol, } \mathrm{MgCl}_{2} \text { and } \mathrm{DNase} \text {, } \\
\text { Chromatography (IMAC), SDS-PAGE, Ni-NTA agarose, lysis buffer, Centrifugal, } \\
\mathrm{NaH}_{2} \mathrm{PO}_{4}(\mathrm{pH} \text { 8), Spectrophotometer/Fluorimeter, PBST (Phosphate Buffered } \\
\text { Saline Tween-20). }\end{array}$ \\
\hline
\end{tabular}




\section{Introduction}

The Green Fluorescent Protein (GFP) originates from the jellyfish Aequorea victoria [1]. GFP is a protein with broad applicability to research regards in medical, cellular and molecular biology [2]. In addition, its spectral characteristics (fluorescence without additional substrates or cofactors) make it useful for in vivo labelling of proteins and cellular structures [2]. Furthermore, GFP fluorescence is either resistant or can recover from a wide range of conditions including $\mathrm{pH}$, temperature, salt concentrations, detergents and proteases [3].

The expression of hexahistidine-tagged GFP in E. coli cells facilitates the process of purification. The hexahistidine-tag has affinity for divalent metal ions and allows the use of Immobilized Metal Affinity Chromatography (IMAC) [4]. IMAC is an efficient method of purification because it is relatively low cost, rapid and can potentially produce high yields of the sample.

The purpose of this investigation was to learn techniques and methods of analysis in molecular cloning and recombinant protein expression and purification. This was achieved by using the sub-cloning of GFP, its subsequent expression and purification as an example. The unique spectral characteristics of GFP make it convenient for following its expression and purification in an undergraduate laboratory during practical classes performed by undergraduate students.

\section{Experimental Procedures}

\subsection{Amplification and Sun-cloning of the GFP Open Reading Frame}

The GFP open reading frame was amplified from the pE-GFP vector by PCR using Vent polymerase: (forward primer: ${ }^{5}$ gcgcagggatccgtgagcaagggcgaggag ${ }^{3}$ reverse primer: 5'caggcgaagctttacttgtacagctcgtc3'). The primers introduced BamHI and HindllI restriction sites into the amplicon allowing subsequent ligation into the PQE30 vector.

The PCR product was purified by phenol/chloroform extraction and ethanol precipitation. The size of the PCR product was verified by agarose gel electrophoresis. A restriction digest was performed on the GFP ORF and the pQE30 vector with $\mathrm{BamHI}$ and HindlII and products purified by Nu-sieve agarose gel electrophoresis.

The GFP ORF was ligated in frame with the 6xHis tag coding sequence of the pQE30 vector. XL-1 Blue E. coli cells, grown in Luria Broth (1\% w/v Bacto tryptone; $0.5 \%$ w/v Bacto yeast extract; $1 \% \mathrm{w} / \mathrm{v} \mathrm{NaCl} ; \mathrm{pH} 7.5$ ) with $100 \mu \mathrm{g} / \mathrm{mL}$ Ampicillin, were made 
Green fluorescent protein purification through Immobilized Metal Affinity Chromatografy and its relevance for Biomedical Science students during Biochemistry practical classes at La Trobe University- Australia

competent using the Inoue method [4] and transformed with the pQE30-GFP construct. Positive clones (grown in the presence of IPTG) were identified by GFP fluorescence under UV light and confirmed through restriction digestion and agarose gel electrophoresis.

\subsection{Expression and Purification of GFP}

Expression of His-tagged GFP was induced in $50 \mathrm{~mL}$ culture at $\mathrm{OD}_{600} 0.6$ via the addition of IPTG (1 $\mathrm{mM}$ final concentration). Zero, 1, and 2 hours time points were sampled and at 2 hours cells were harvested, pelleted, re-suspended in lysis buffer $(50 \mathrm{mM}$ $\mathrm{NaH}_{2} \mathrm{PO}_{4}, \mathrm{pH} 8 ; 300 \mathrm{mM} \mathrm{NaCl} ; 0.2 \mathrm{mg} / \mathrm{mL}$ ) lysozyme was added fresh; [5] and incubated at $37^{\circ} \mathrm{C}$ for 20 minutes. $\mathrm{MgCl}_{2}$ and $\mathrm{DNase}$ were added to a final concentration of $3 \mathrm{mM}$ and $4 \mu \mathrm{g} / \mathrm{mL}$ respectively and cells were incubated at room temperature for 10 minutes, before lysis was completed by sonication.

After that, $1 \mathrm{~mL}$ of lysate was centrifuged to pellet any cellular debris and the supernatant retained for IMAC purification [6] of the His-tagged GFP.

An aliquot was put aside (crude fraction) for SDS-PAGE, the rest incubated with $100 \mu \mathrm{L}$ of a $50 \%(\mathrm{w} / \mathrm{v})$ slurry of Ni-NTA agarose beads in lysis buffer at room temperature for 1 hour on a rotary mixer.

After centrifugation at $1500 \mathrm{xg}$ for 2 minutes, the supernatant (unbound fraction) was collected and the pellet re-suspended in $1 \mathrm{~mL}$ wash buffer $\left(50 \mathrm{mM} \mathrm{NaH}_{2} \mathrm{PO}_{4}, \mathrm{pH}\right.$ 8; $300 \mathrm{mM} \mathrm{NaCl} ; 20 \mathrm{mM}$ imidazole) and incubated for 5 minutes at room temperature.

The supernatant (washed fraction) was again collected and the wash repeated 3 times each time discarding the supernatant. The washed beads were re-suspended and incubated for 5 minutes in elution buffer $\left(50 \mathrm{mM} \mathrm{NaH}_{2} \mathrm{PO}_{4}, \mathrm{pH}\right.$ 8; $300 \mathrm{mM} \mathrm{NaCl} ; 250 \mathrm{mM}$ imidazole).

The agarose beads were pelleted at high speed and the supernatant (eluted fraction) collected.

Following that, $10 \mu \mathrm{L}$ of all fractions collected were mixed with equal volume SDSPAGE loading buffer. Zero, 1, and 2 hours post-induction time course samples were resuspended in $100 \mu \mathrm{L} \mathrm{H}_{2} \mathrm{O}$ and 100 $\mu \mathrm{L}$ SDS-PAGE loading buffer per $\mathrm{OD}_{600}$ unit reading. 20 $\mu \mathrm{L}$ of all samples $(0,1,2$ hours post-induction; crude, unbound, washed, and eluted fractions) were run on $10 \%$ SDS-PAGE [7] for analysis. Proteins were then visualized by Coomassie staining. 


\subsection{Quantification of GFP}

Both the total protein and the specific GFP concentrations were determined for the crude lysate and final eluant from the Ni-NTA agarose. Protein content was determined using the Bio-Rad DC assay with bovine serum albumin as the standard.

GFP concentration was determined using a fluorescent assay performed in an opaque 96-well microliter plate. GFP fluorescence was measured using a Spectra Max M2 Spectrophotometer/Fluorimeter (Molecular Devices) with excitation at $485 \mathrm{~nm}$, emission at $538 \mathrm{~nm}$ and emission cut-off set to $530 \mathrm{~nm}$.

A highly purified and previously characterized GFP sample was made available to the class to use as a standard. Bacterial lysate from cells not expressing GFP was used to control for auto fluorescence and quenching of fluorescence within the samples.

\subsection{Western blot Analysis}

Dilutions of crude lysate and GFP eluant were electrophoresed on a $12 \%$ SDSPAGE gel and transferred to a nitrocellulose membrane. After blocking for 1 hour in $5 \%$ (w/v) milk powder in PBST (phosphate buffered saline with $0.2 \%(\mathrm{v} / \mathrm{v})$ Tween-20) the membrane was probed with a 1/1000 dilution of rabbit anti-GFP (Cell Signaling Technology) in PBST for 2 hours at room temperature.

The membrane was washed with three changes of PBST over 15 minutes and probed with mouse anti-rabbit IgG conjugated to alkaline phosphatase. After washing again in PBST, bands were visualized using NBT/BCIP until maximum colour development was observed.

\section{Results}

The PCR of the GFP open reading frame (ORF) from pE-GFP yielded sufficient amounts of GFP cDNA for ligation into the PQE30 vector a single band of approximately 750-850bp was visible (figure 1). 


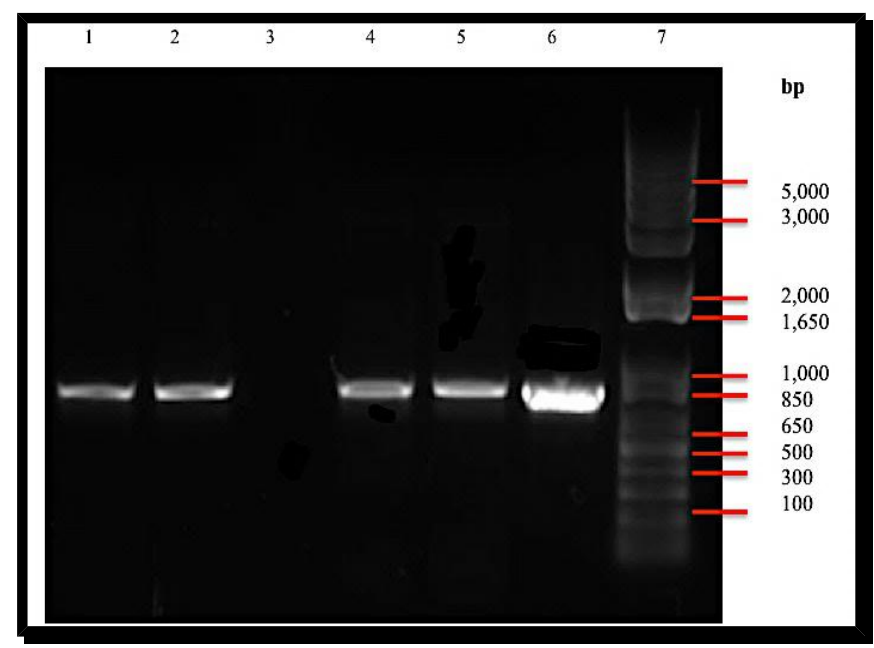

Figure 1. Agarose gel (0.8\%) showing PCR amplification product of cDNA from pE-GFP vector colored with ethidium bromide $(0.2 \mathrm{ug} / \mathrm{mL})$. In the lines 1, 2, 4, 5 and 6 contain PCR product, lane 3 is used as a negative control without DNA sample added, and line 7 contains Invitrogen $1 \mathrm{~kb}$ Plus DNA Ladder as a pattern (sizes indicated).

A plasmid mini-prep and restriction digest was performed to confirm the successful subcloning of the GFP ORF from the $\mathrm{pE-GFP}$ vector to $\mathrm{PQE} 30$. Positive and negative GFP clones (E. coli PQE30 transformants) were first identified using GFP fluorescence under UV light according to [8].

Two colonies (+/-GFP) were selected for overnight culture from which a mini-prep was performed and samples of plasmid DNA incubated with or without BamHI and HindIII restriction enzymes. Products were run on an agarose gel to separate DNA fragments (figure 2).

An insert corresponding to approximately $750 \mathrm{bp}$ was observed for digested plasmid DNA from the positive GFP colony treated with restriction enzymes. The absence of such a band in the other lanes verifies the success of the GFP sub-cloning into the PQE30 vector (figure 2). 
Green fluorescent protein purification through Immobilized Metal Affinity Chromatografy and its relevance for Biomedical Science students during Biochemistry practical classes at La Trobe University- Australia

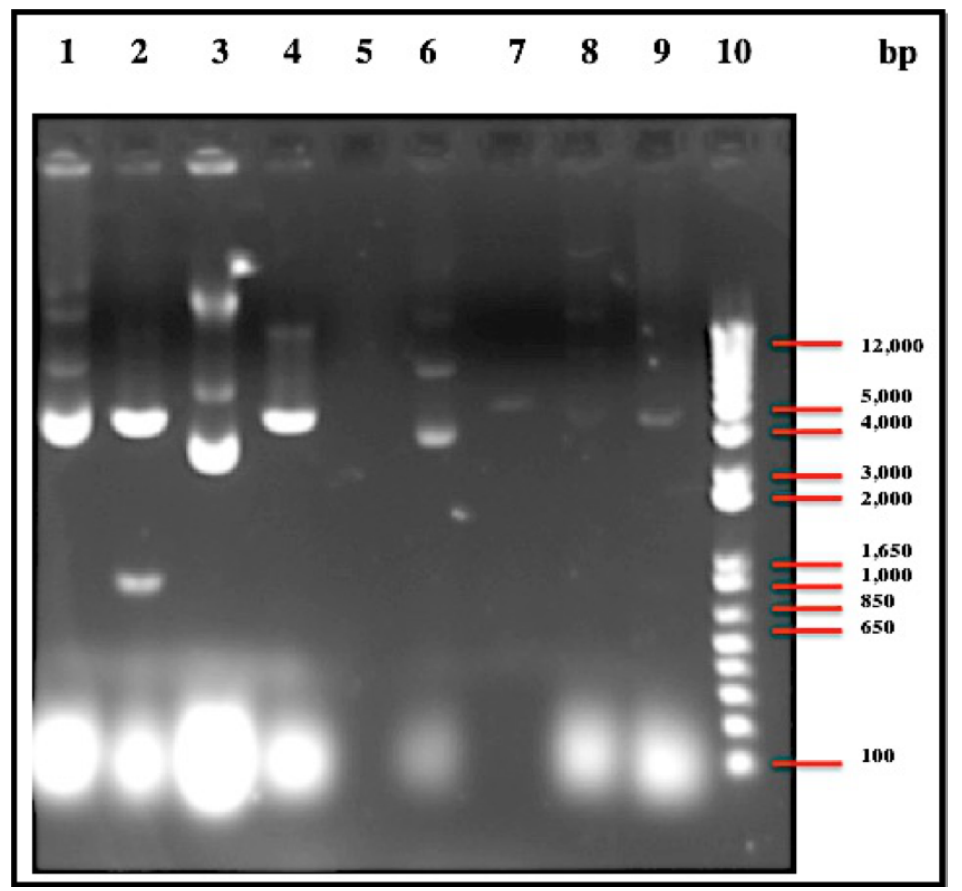

Figure 2. Digestion of $\mathrm{pQ30}$ vector +/- GFP performed with BamHI and Hind III showed in agarose gel $0.8 \%$ dissolved in 1x SYBR SAFE.

The expression of His-tagged GFP was induced by the addition of IPTG. Cell samples were immediately collected prior 1 and 2 hours post-induction carried out a time course of the induction process. The proteins present in the samples were separated by SDS-PAGE and visualized by coomassie blue staining (figure 3 ).

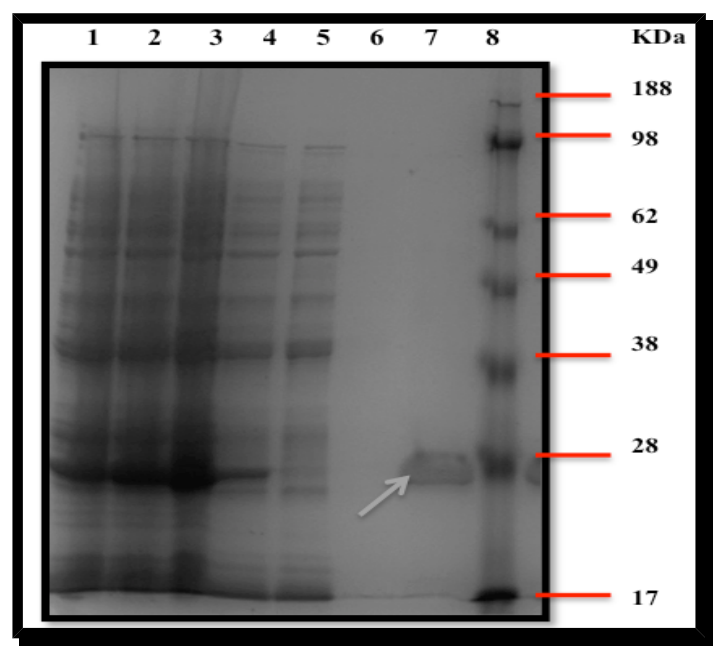

Figure 3. Analysis of GFP fusion protein purification with $10 \%$ SDS-PAGE. Identified in lane 7 is the purified protein representing a band size between 17 and $28 \mathrm{kDa}$.

A band of approximately $28 \mathrm{kDa}$ was observed to increase in amount following the 
Green fluorescent protein purification through Immobilized Metal Affinity Chromatografy and its relevance for Biomedical Science students during Biochemistry practical classes at La Trobe University- Australia

induction time course. Another band of similar size was the major constituent eluted from the Ni-NTA agarose beads. A similar sized band was specifically detected by western analysis in both crude lysate and eluant fractions (figure 4).

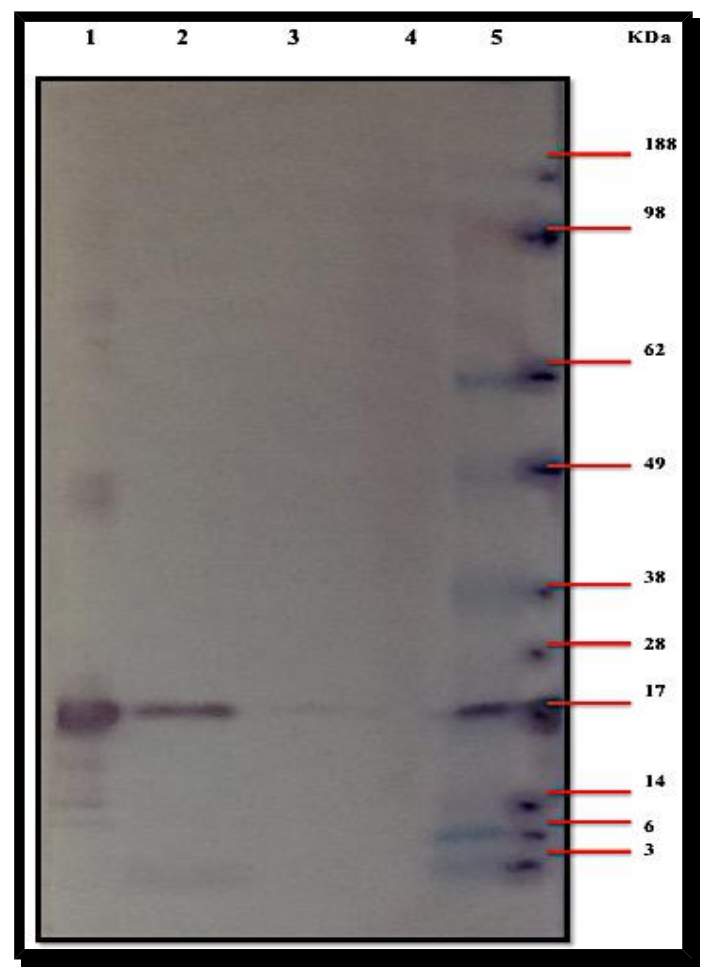

Figure 4. Analysis of GFP fusion protein with Western blotting. Western blot blocked with defatted milk power in TBS/T, using primary antibody 1/2000 rabbit anti-GFP and secondary antibody 1/1000 goat antirabbit IgG - AP linked. Lane 1 representing crude $E$. coli extract 1/5.

The analysis of GFP purity demonstrated that the crude lysate contained $0.11 \mathrm{mg}$ GFP/mg protein and the eluant fraction contained $0.34 \mathrm{GFP} / \mathrm{mg}$ proteins. The purification of GFP resulting from the IMAC procedure was therefore approximately 3-fold.

\section{Discussion}

The aim of this practical was to utilize the unique properties of GFP to illustrate techniques and methods of analysis in molecular cloning and recombinant protein expression and purification during Biochemistry practical classes of the undergraduate course. The steps taken towards this involved subcloning the GFP ORF from the pE-GFP to the pQE30 vector, the transformation of E. Coli with the pQE30-GFP construct, and the expression and IMAC purification of His-tagged GFP followed by analysis by SDS-PAGE and western analysis.

The successful subcloning of the GFP ORF into the pQE30 vector was confirmed by plasmid purification, restriction digest and agarose gel electrophoresis. Two colonies 
were identified under UV light as +GFP and -GFP, and plasmids-GFP supercoiled forms of the uncut plasmid DNA correlates with the presence and absence of the GFP ORF. That both cut and linearized plasmids have migrated to the same position, and the presence of an extra band found only with RE treated +GFP of approximately 750bp (the size of the GFP ORF is expected to be 740bp) further confirms the successful sub-cloning of the GFP ORF into the $\mathrm{PQE} 30$ vector.

From these were extracted and treated with and without restriction digestions. Smears of the upper band indicate the presence of genomic DNA. The remaining lower bands contain plasmid DNA in various conformations.

GFP was successfully expressed, induced and partially purified. Following IPTG induction band of approximately $28 \mathrm{kDa}$ can be seen increasing markedly from 0 to $2 \mathrm{hrs}$, with the density of all other bands remaining stable. The size of GFP is approximately $27 \mathrm{kDa}[9]$ and with His-tag would approximate 28kDa. The IMAC purification of His-tagged GFP also appears to have been successful: only one band can be visualized by coomassie blue staining of the SDS-PAGE gel in the lane containing the final product of the purification procedure.

This band migrated to the same point as the band, which increased from 0 to $2 \mathrm{hr}$ post induction, and again correlates with the expected size of His-tagged GFP [5-11]. In addition the eluant had the characteristic appearance and fluorescence under UV light expected of GFP in solution.

The purification of GFP by IMAC only achieved an approximate 3-fold purification [3-6]. The efficient results of this project can be indicated through the result obtained by the sizes of the DNA after PCR reaction, the protein band and the restriction fragment digestion of the PQE30 vector, they remain after the purification procedure. After IMAC purification process a green fluorescence was revealed under UV light as a final product for this procedure.

Western analysis of the purified protein further confirmed the specific expression and purification of GFP. Although the fold purification of GFP could be improved, our results confirm that using His-tag protein allow its purification through IMAC with abundant yield of this protein. Purification by IMAC is the most common method for protein purification [13] as it is a straight-forward technique with a variety of applications.

\section{Analysis of teaching and learning aspects}

In order to achieve the learning subject purposes theoretical and practical classes 
Green fluorescent protein purification through Immobilized Metal Affinity Chromatografy and its relevance for Biomedical Science students during Biochemistry practical classes at La Trobe University- Australia

compounded the learning methodology of Advanced Biochemistry. The theoretical classes happened every Wednesday from 14:00 to 15:00 pm while the practical classes happened every Thursday from 12:00 to $18: 00 \mathrm{pm}$.

During the theoretical classes students were introduced to all of the necessary content to understand the practical classes related tomolecular cloning, protein expression and purification. Through digital tools, such as power point slides, the professor explained all the content to all students clarifying possible doubts about the theme.

The practical classes happened at the La Trobe Institute for Molecular Science (LIMS). At the start of each practical session a students met in smaller groups where are pair of students presented a short tutorial to the rest of the class detailing the upcoming work and/or explaining data from the previous session. These student-led tutorials were facilitated by graduate student mentors familiar with the practicals.

Thereby, students would have a better understanding of the theory and also know what to do and how to perform all the procedures and appropriate techniques. Furthermore, the mentors were available to help all of students during the experiments.

The spectral properties of GFP make it useful for illustrating techniques in protein expression and purification and allowed theoretical knowledge to be put into practice in the laboratory. The assessment learning was composed by theoretical and practical tests, both supervised by mentors and the subject supervisor. The content covered during the theoretical lectures and experimental activities comprised part of the final exam, serving as the method of assessment of students knowledge.

\section{Education Impact}

The GFP study was a useful tool to demonstrate for all of the involved students the basis of purification and cloning of the analysed protein. Most of the class had no prior experience in these techniques. Purification of GFP during practical classes, allowed close contact with a relevant and advanced area related to purification, cloning and protein expression. In addition, the involvement of the entire student groups was essential to achieve desired results.

Using IMAC and the associated methodologies, permitted the experiments to be performed in a modern and efficient manner. Furthermore, the expected results were achieved often in corroboration with other students developing cooperative teamwork and reinforcing the acquired knowledge and practical skills.

Students at La Trobe University complete formal feedback evaluations on the 
Green fluorescent protein purification through Immobilized Metal Affinity Chromatografy and its relevance for Biomedical Science students during Biochemistry practical classes at La Trobe University- Australia

quality of teaching for all of their subjects. Qualitative feedback on this subject were overwhelmingly positive with many comments highlighting the usefulness of the integrated GFP practicals and the link between theory and practical work. Quantitative feedback on the overall quality of the subject was also positive with student satisfaction for the subject scoring higher than the institute average.

\section{Final Considerations}

The use of IMAC showed great effectiveness to purify GFP protein. Known as an excellent technique for purification, IMAC has several advantages related to its reproducibility, price and productivity. It uses simple procedures which are easily understood by students.

Because of its great applicability in a range of procedures, its use makes it a very useful tool commonly applicable in laboratory for experiments. However, it is notable that IMAC technique is capable to be enhanced when worked together with other technologies, such as tandem affinity purification or other techniques such as size exclusion chromatography.

\section{References}

[1] Gerdes HH, Kaether C. Green fluorescent protein: applications in cell biology. Federation of European Biochemical Societies. 1996, 389. p. 44-7.

[2] Zimmer M. Green Fluorescent Protein (GFP): Applications, Structure, and Related Photophysical Behavior. American Chemical Society. 2002; 102. p. 759-781.

[3] Ehrmann MA, Scheyhing CH, Vogel RF. (2001). In vitro stability and expression of green fluorescent protein under high pressure conditions. Letters in Applied Microbiology. 2001; 32; 230-234.

[4] Inoue $\mathrm{H}$, Nojima $\mathrm{H}$, Okayama $\mathrm{H}$. High efficiency transformation of Escherichia coli with plasmids. Gene.1990; 96(1); 23-8.

[5] Sambrook J, Fritsch E.F, Maniatis T. (1989). Gel electrophoresis of DNA. In: Sambrook, J., Fritsch, E.F. and Maniatis, T. (Eds.) Molecular Cloning: a Laboratory Manual. New York: Cold Spring Harbor Laboratory Press, Cold Spring Harbor, NY, USA, chapter 6.

[6] Hochuli E, Dbeli H, Schacher A. (1987). New metal chelate adsorbent selective for proteins and peptide containing neighbouring histidine residues. J Chromatogry. 1987; 411: 177-184/

[7] LaemmLi UK. Cleavage of Structural Proteins during the Assembly of the Head of Bacteriophage T4. Nature. 1970; 227: 680-685. doi: 10.1038/227680a0

[8] Dieryck W, Noubhani AM, Coulon D, Santarelli X.. Cloning, expression and two-step purification of 
Green fluorescent protein purification through Immobilized Metal Affinity Chromatografy and its relevance for Biomedical Science students during Biochemistry practical classes at La Trobe University- Australia

recombinant His-tag enhanced green fluorescent protein over-expressed in Escherichia coli. Journal of Chromatograpy. 2003; 726: 153-9.

[9] Prasher DC, Eckenrode VK, Ward WW, Prendergast FG, Cormier MJ. Primary structure of the Aequorea victoria green-fluorescent protein. Gene. 1992; 111(2): 229-33.

[10] Zech K, Frei RW. Selective sample handling and detection in high performance liquid chromatography. Journal of Chromatograph library. 1989; 39.

[11] Porath J, Jan C, Ingmar O, Greta B Metal chelate affinity chromatography, a new approach to protein fractionation. Nature. 1975; 258: 598-599.

[12] Lowry OH, Rosebrough NJ, Farr AL, Randall RJ. Protein Measurement with the Folin Phenol Reagent. Journal of Biological Chemistry, 1951; 193: 265-275.

[13] Wang L, Quan C, Liu B, Xu Y, Zhao P, Xiong W, Fan S. (2013). Green Fluorescent Protein (GFP)-Based Overexpression Screening and Characterization of AgrC, a Receptor Protein of Quorum Sensing in Staphylococcus aureus. Int. J. Mol. Sci. 2013; 18470-18487; doi: 10.3390/ijms140918470.

[14] Kaplow I M, Singh R, Friedman A, Bakal C, Perrimon N, Berger B. (2009). Enabling IMAC purification of low abundance recombinant proteins from E. coli lysates. Nature methods. 2009; 6(7): 477-8. 